\title{
National Licensure Exam for Brazilian Nurses: why and for whom?
}

\author{
Exame de suficiência para a Enfermagem brasileira: por quê e para quem? \\ Examen de suficiencia para la enfermería brasileña: ¿por qué y para quién?
}

Kênia Lara da Silva', Ivone Evangelista Cabral"
'Universidade Federal de Minas Gerais, Nursing School. Belo Horizonte, Minas Gerais, Brazil.
"Universidade Federal do Rio de Janeiro, Nursing School Anna Nery. Rio de Janeiro, Brazil.
How to cite this article:
Silva KL, Cabral IE. National Licensure Exam for Brazilian Nurses: why and for whom?. Rev Bras Enferm [Internet].
2018;71(4):1692-9. [Thematic issue: Education and teaching in Nursing] DOI: http://dx.doi.org/10.1590/0034-7167-2017-0929

Submission: 01-10-2018 Approval: 03-30-2018

\begin{abstract}
Objective: To analyze critically the reasons for regulating a National Licensure Exam for Brazilian Nurses (NLEXB-N). Method: Qualitative study with secondary source applying the critical discourse analysis to situate context and intertextuality in the establishment of a new social practice. We analyzed data from legal documents regulating the National Licensure Exam of other professions in Brazil, the Educational Census, the Survey of Brazilian Nursing Profile and global nursing literature. Results: Four themes were explored: Brazilian experiences with this exam; nursing experiences in other countries; effects of the exam on the examinees; NLEXB-N in Brazil: what purposes could we present? Final considerations: The National Licensure Exam for Brazilian Nurses is a measure of individual accountability that increases social injustice, inequality and inequity. We must pay attention to the consequences of its application, based on evidences produced in the area.
\end{abstract}

Descriptors: Professional Practice; Nursing Education; Professional Training; Regulation; Professional Skills.

\section{RESUMO}

Objetivo: Analisar criticamente as motivações para a regulamentação do exame de suficiência na Enfermagem brasileira. Método: Estudo qualitativo com fonte secundária aplicando-se a análise crítica do discurso para situar o contexto e a intertextualidade na instauração de uma nova prática social. Dados de documentos legais de regulamentação do exame de suficiência de outras profissões no Brasil, do Censo da Educação, do Perfil da Enfermagem no Brasil e literatura de Enfermagem global foram analisados. Resultados: Exploraram-se quatro temas: experiências brasileiras com o exame; experiências da Enfermagem de outros países; efeitos do exame sobre os examinandos; exame de suficiência para a Enfermagem no Brasil: que sentidos poderiam ser construídos? Considerações finais: O exame de suficiência para a Enfermagem é uma medida de responsabilização do indivíduo que acentua a injustiça, desigualdade e iniquidade sociais. É necessário atentar para as consequências de sua aplicação, a partir de evidências produzidas na área.

Descritores: Prática Profissional; Educação em Enfermagem; Capacitação Profissional; Regulação; Competência Profissional.

\section{RESUMEN}

Objetivo: Analizar críticamente las motivaciones para la regulación del examen de suficiencia en la enfermería brasileña. Método: Estudio cualitativo con fuente secundaria aplicando el análisis crítico del discurso para situar el contexto y la intertextualidad en la instauración de una nueva práctica social. Se analizaron datos de documentos legales de regulación del examen de suficiencia de otras profesiones en Brasil, del Censo de la Educación, del Perfil de la Enfermería en Brasil y la literatura de enfermería global. Resultados: Se analizaron cuatro temas: experiencias brasileñas con el examen; experiencias de la enfermería de otros países; los efectos del examen sobre los examinandos; examen de suficiencia para la enfermería en Brasil: ¿qué sentidos podrían ser construidos? Consideraciones Finales: El examen de suficiencia para la enfermería es una medida de responsabilización del individuo que acentúa la injusticia, desigualdad e iniquidad sociales. Es necesario atentar para las consecuencias de su aplicación, a partir de evidencias producidas en el área.

Descriptores: La Práctica Profesional; La Educación en Enfermería; La Capacitación Profesional; La Regulación; La Competencia Profesional. 


\section{INTRODUCTION}

Many movements in the fields of Health, Education and Nursing show advances and setbacks, which marked the years 2016 and 2017. Among those, we highlight the inclusion of Nursing in the system of regulation, supervision and evaluation of the National Health Council through the Intersectoral Commission of Human Resources $(\mathrm{CNS} / \mathrm{CIRH})$, with the publication of Decree 8,754, of May $102016^{(1)}$.

The National Health Council (Conselho Nacional de Saúde - CNS) also approved the Ordinance 515 of October 7, 2016 (2), opposing the creation of Distance Education (EAD) courses in health, which will focus directly on Nursing. It is the only health profession with representation of workers in the CNS plenary, with undergraduate courses in the modality of distance education offered in the country.

Among the setbacks we can find the approval of Law 13.415 from February 16, 2017(3), which, among other things, amends Law on Brazilian Education Guidelines and Bases (LDB) 9.394, from December 20, 1996 (3-4). Particularly, it is concerned with the repeal of the obligation to have, in high school, disciplines that deal with the field of knowledge of philosophy and sociology previously considered needed to exercise citizenship.

We highlight the Constitutional Amendment 95, from December 15, 2016 (5), entitled "PEC (The acronym stands for the Brazilian Proposed Constitutional Amendment) which may represent an addition to or modification of the text of the original Constitution of Major Public spending". It freezes spending on health and education for the next 20 years, by instituting a new fiscal regime. In theory, even if there is demographic expansion, the use of public funds will be limited to those of the budget of 2017.

In the field of Nursing, Bill 4930/2016 ${ }^{(6)}$ is being processed in the Chamber of Deputies in Brasília State. This Project amends the Nurses Practice Act, regulated under No. 7.498, June 25, $1986^{(7)}$, to include in it the obligation to perform a National Licensure Exam for Brazilian Nurses to obtain professional license on the State Council of Nursing (Conselho Regional de Enfermagem - COREn). This project is processed under an ordinary regime and its last move was on October 30, 2017 in the Public Service, Administration and Service Committee (Comissão de Trabalho, de Administração e Serviço Público - (CTASP), receiving a favorable opinion from the rapporteur.

Among the fundamentals of Bill 4930/2016, we highlight the use of data from the Survey of Brazilian Nursing Profile ${ }^{(8)}$, published by the Federal Council of Nursing (Conselho Federal de Enfermagem - COFEn). It presents undergraduate bachelor of nursing in the modality distance education implement only $7.79 \%$ of the internship program, failing to comply with the National Curriculum Parameters of 2001 (Diretrizes Curriculares Nacionais - DCN) for all nursing undergraduate ${ }^{(9)}$.

In general, a National Licensure Exam is a kind of Uniform Certified Public Accountant Examination that is part of the skill assessment system. Studies in this arena outline three areas of this assessment: for registration or license (to exercise or professional practice), evaluation for certification and assessment for accreditation ${ }^{(10-12)}$.

The first level/field occurs when there is application of an examination to obtain a license or professional registration. In the United States, for example, this is when Registered Nurses (RN) or Licensed Practical Nurses (LPN) holds an individual and private license, resulting from an evaluation that states they have acquired basic knowledge required for practicing.

The license issued by a regulatory body (such as the National Council of State Boards of Nursing [NCSBN] in the USA) warrants the public that nurses have complied with predetermined standards for professional practice. Without this license, nurses are not Licensed or Registered, because what provides them the mandatory status to exercise is registration, not the scope of training. That is, access to the career is not due to the termination of training at different levels, but by an examination that certifies the knowledge acquired ${ }^{(13-15)}$.

The regulation of career access through examinations is based on the product of training process, without direct focus on the educational system or gaps of the training process. Thus, the reason for approval of the proposed National Licensure Exam for Brazilian Nurses (NLEXB-N) in Brazil seems to be inconsistent, which focuses on the premise that, when regulating access, it inhibits training nurses in the distance education modality. Its application should be problematic since it is situated in the field of regulation of access to professional career and not in the training process, because in Brazil formal educational training and regulatory professional practice belong to different fields of legislation.

In addition, the proposal NLEB-N addresses measurement of skills related to learning how to know that is one of the three skills foreseen for training nurses in Brazil by the DCN. It is recognized that its application as a test of knowledge assessment has proved insufficient to evaluate the competence acquired by doing (skills) and being professional (attitudes) in the professional field.

Experiments with other professions that have adopted $\mathrm{Na}$ tional Licensure Exam (NLEX) in Brazil demonstrate their weak inhibitory influence on training. Thus, we question: what is the meaning of applying a NLEX for career access? How effectively will this exam measure and qualify, in the face of the problem of nursing education in the modality of distance education?

\section{OBJECTIVE}

To analyze critically the reasons for regulating National Licensure Exam for Brazilian Nurses.

\section{METHOD}

\section{Ethical aspects}

The data discussed in this article is of public domain with unrestricted access, without the identification of individuals.

\section{Type of study}

The construction of this text was based on analysis of secondary sources, results of the Survey of Brazilian Nursing Profile ${ }^{(8)}$ and the Higher Education Census (2016), of legal tools that regulate teaching and practice in different areas (Nursing, Law and Accounting) and global mapping of National Licensure Exam. This information allowed us to understand the occupational contexts of countries, which have been adopted a National Licensure Exam for nurses. 


\section{Source, collection and organization of data}

We have analyzed the following legal documents: a) Bill 4930/2016 ${ }^{(6)}$, which amends Law $7.498^{(7)}$ from June 25,1986 ; b) Law 12.249 from June 11, 2010 ${ }^{(17)}$ and the Federal Accountancy Council Ordinance 1.301, from September 13, 2010 ${ }^{(18)}$; c) Law 8.906 of July 4, $1994^{(19)}$, which regulates the Brazilian Bar Association Constitution and Bylaws. We have consulted the National Council Licensure Examination- Registered Nurse (NCLEX-RN) web pages in the United States and Canada - Related Resources section (https://www.ncsbn.org/nclex.htm), with information about the application of this assessment.

We also carried out a bibliographical search that allowed us to understand the proposition of National Licensure Exam for Brazilian Nurses, changes of that debate, challenges and criticisms, in an open period, resulting in a first publication in 1991. These texts focus on the effects and how National Licensure Exam for Brazilian Nurses impacts on the examinee.

\section{Data analysis}

The critical discourse analysis, in Fairclough's perspective ${ }^{(20)}$, was applied to understand the nature of discourse contextualized, since every discursive practice is a reflection of a social practice, marked by intertextualities from multiple voices and contexts. In the three-dimensional analysis, discourse is related to a text previously produced (pre-text), modifying it and being modified by context. Thus, the discourse of National Licensure Exam for Brazilian Nurses (NLEX-N) in discussion in Brazil has as a pretext, more experience in nursing in other countries than in the two Brazilian professions, which are not in the health area. A discursive practice developed must be described, interpreted and explained according to the social criticism of discourse.

The result of this analysis allowed us to formulate three themes: Brazilian experiences with National Licensure Exam for Brazilian Nurses, experiences with nursing exams in other countries, National Licensure Exam for Brazilian Nurses for nursing in Brazil: what purposes could we present?
Law area in Brazil also has a National Licensure Exam for Law (Exame de Suficiência), called the Entrance Exam, by the Order of Attorneys of Brazil (Ordem dos Advogados do Brasil - OAB). The Career Entrance Exam initially provided for in Article 48, item III, of Law 4.215/1963, is currently regulated by Law 8906 of July 4, 1994, which create the Statute of the Attorneys and the Order of Attorneys of Brazil.

For registration as a lawyer, it is necessary ... approval in the Bar Exam (Article 8, Section VII). The Bar Exam is regulated by the Federal Council of the OAB (paragraph 1 of article 8). It is OAB's sole responsibility ... to hold the Bar Exam (art. 58) ${ }^{(19)}$.

From public domain documents available on websites, there are experiences in countries (Figure 1) from North America (United States and Canada), Europe (Portugal, England, Ireland), Africa (Kenya and South Africa), Asia (China, Hong Kong, Pakistan, Japan, Philippines, New Zealand) and Australia, with qualification exams for undergraduates of nursing education having access to professional careers. No country in Central and South America adopts this type of examination as a prerequisite for professional practice.

Regarding the experiences with nursing National Licensure Exams in other countries, the most noteworthy are those from the United States, Canada, Australia and China.

The National Licensure Exam has been adopted by the United States since 1982 and applied by the National Council Licensure Examination (NCLEX), nationwide for nurses' license. There are two types: NCLEX-RN (Registered Nursing) and NCLEX-PN (Practice Nursing) ${ }^{(21)}$.

NCSBN is dedicated to developing psychometrically sound and legally defensible nurse licensure and certification examinations consistent with current practice. These exams include NCLEX-RN and NCLEX-PN Examinations, National Nurse Aide Assessment Program (NNAAP) ${ }^{(13)}$.

Upon completion of a bachelor's degree at a nursing school, the NCLEX exam is performed to obtain the nursing license, a permit for the approved individual to practice as a registered nurse or practical nurse.

\section{RESULTS}

Brazilian experiences with National Licensure Exam are limited to Law and Accounting professions, both regulated by law. In Accounting, the examination was instituted by Law 12.249 , June 11, 2010, which amended Decree-Law 9.295 of May 27, 1946, and Decree Law 1040, October 21, 1969 to regulate the insertion of the accounting sufficiency test as a basic and mandatory requirement for obtaining professional registration.

The professionals referred to in this DecreeLaw may only exercise the profession after the regular completion of the Bachelor of Science in Accounting, recognized by the Ministry of Education, approved in the National Licensure Exam for Accounting and registered in the State Council of Accounting to which they are subject (Art. 12, Law 12.249, of June 11, 2010) ${ }^{(17)}$.

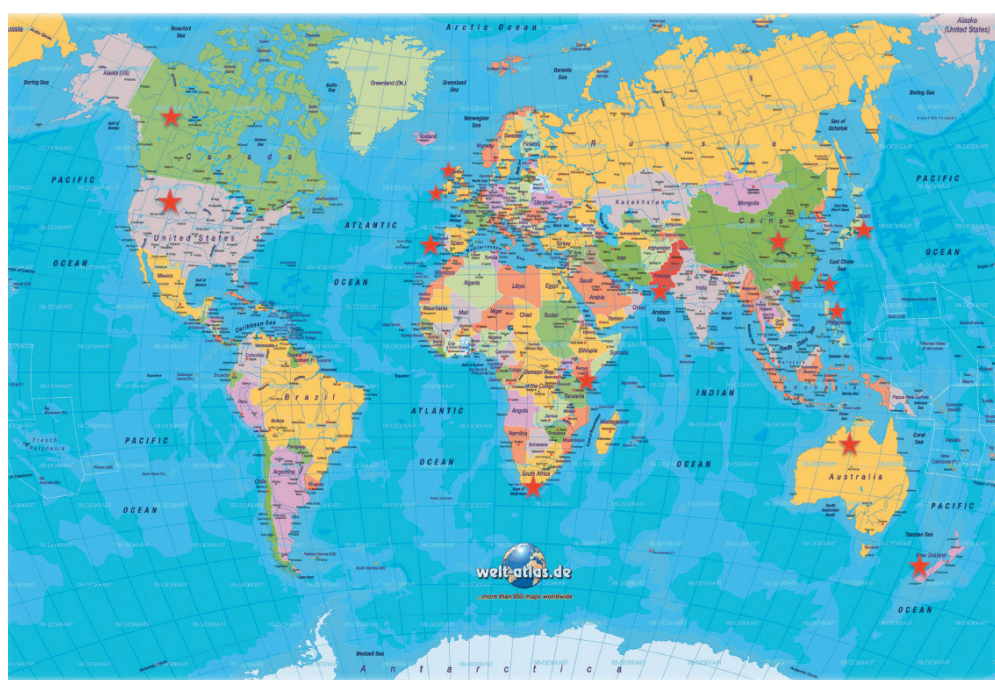

Figure 1 - Countries that take a National Licensure Exam for Registered Nurses in the world 
Canada has been applying this exam since 1994. In 2015, the same American examination was adopted by NCLEX, but applied by the province and not nationally as in the United States.

As of 2015, the 11 provincial/territorial $R N$ regulators chose the National Council of State Boards of Nursing (NCSBN) as the provider of the Canadian RN entry-to-practice exam ${ }^{(22)}$.

NCLEX in Canada is new and for that reason, information is scarce. Starting in January 5th, 2015, the NCLEX-RN replaces the CRNE (Canadian Registered Nurse Examination) as Canada's national examination for those applying to be a registered nurse. There are TWO applications you will need to submit (there may be more for international/foreign educated students). In Canada, nurses don't get licensed for the whole country. Each nurse is usually licensed in one province at a time ${ }^{(23)}$.

In Australia, the National Accreditation and Registration System for health professionals began in July 2010, through the National Regulation of Health Professionals.

The National Registration and Accreditation Scheme for health care practitioners was established by Australia's state and territory governments and commenced on July 1, 2010. It is governed by the Health Practitioner Regulation National Law... Each profession has a National Board which regulates the profession, registers practitioners and develops standards, codes and guidelines for the profession. (See at: Australian government of Health ${ }^{(24)}$.

In China, all nursing undergraduates are required to carry out the National Nurse Qualification Examination (NNQE) as a requirement to register and practice nursing practice ${ }^{(25)}$. In Japan, to become a public health nurse, midwife, or nurse, it is essential to complete a mandatory curriculum in an educational institution and pass a national examination, then obtain a license granted by the Minister of Health, Labor and Welfare University for All Program ${ }^{(26)}$.

The third theme corresponds to the National Licensure Exam for nurses in Brazil: what purposes could we present? According to justifications in Bill 4930/2016, the National Licensure Exam is a way of coping with the poor quality of training, due to the expansion of nursing courses in the country, particularly those graduating from distance courses. "The great number of Nursing courses in the country, including distance education, many with questionable quality".

In the EAD teaching modality, practical classes represent only $7.79 \%$ of the total hours of courses, which is in complete disagreement with what the DCN of Nursing Undergraduate Course prescribes. It is certain that professionals trained by distance education may not have received indispensable knowledge for the profession, without a doubt ${ }^{(6)}$.

Possibly, a purpose could come from the understanding that the examination to regulate the access can overcome the limits of evaluations intrinsic to the process of qualification for certain professional exercises. Such a measure could be justified where training (with all its evaluation processes) was either incapable or insufficient to attest the skills of undergraduates. In this context, an external examination of the training system is an intertextuality that would fulfill the function of evaluating what would be the scope of the training system.

We recognize the challenges posed by the disorderly growth of courses and, specially those developed in the distance modality; this is another intertextuality that reflects the contradiction of democratization of access with low quality of offer of teaching conditions. However, the National Licensure Exam seems to have no direct impact on these aspects, given the results in Law and Accounting, which has little influence on the demands of those interested in taking these courses.

We must also consider that the expansion of Nursing Higher Education in Brazil meant a democratization of low-income population access to university, mostly private, with great funding by the government. Data from the Higher Education Census of 2016 indicates that, among students who entered the higher education in 2016, 82.3\% were enrolled in private institutions. The vacancies of enrollments in the public university education corresponded to $17.3 \%$.

Regarding nursing, it can be seen in Figure 2 that, in the last five years, there is a disproportion between the number of enrollments, admissions and undergraduates. Considering that the regular tuition time of the course is five years, among those who joined in $2011(n=98,617)$, only $35.7 \%(n=35,195)$ completed the course in 2016.

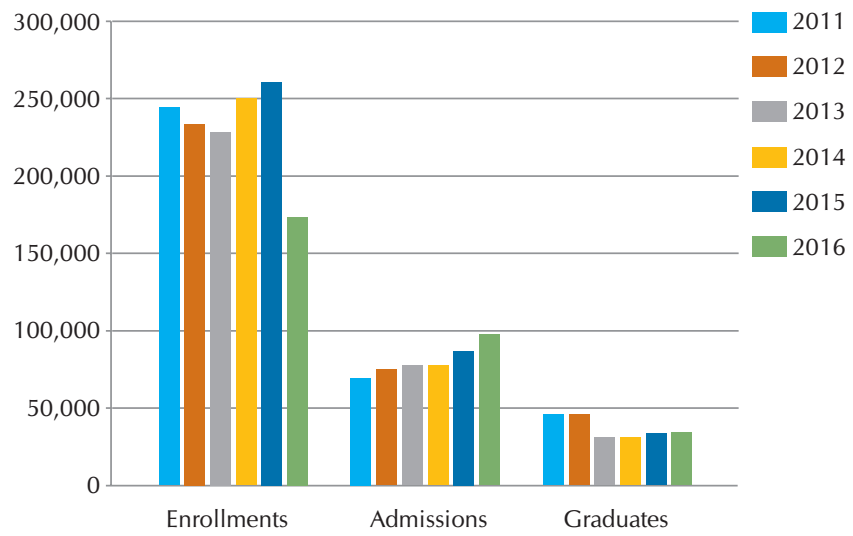

Source: Higher Education Census, 2016

Figure 2 - Evolution of nursing education, according to the number of enrollments, admissions and undergraduates, Brazil, 2011-2016

The expansion of vacancies in the private network was funded by the public through scholarships, such as the University for All Program (ProUni) or the Loan Fund for Higher Education Students (FIES).

Law 11.096 from January 13, 2005, established ProUni, regulated the activities of charities in higher education and amended Law 10.891 from July 9, 2004, under the management of the Ministry of Education. Among other purposes, ProUni grants full and partial scholarships in undergraduate and sequential courses of specific training in private institutions of higher education for those with a maximum per capita family income of three minimum wages and selected according to: 
...(50\%) or $25 \%$ (twenty five percent) for students of undergraduate and sequential courses of specific training, in private institutions of higher education (...) Full scholarship will be awarded to Brazilians... whose monthly family income per capita does not exceed the value of up to one (1) minimum wage and 1/2 (one-half). Partial (50\%) or twenty-five percent (25\%) [...] scholarships will be awarded to Brazilians ... whose monthly family income per capita does not exceed up to three (3) minimum wages, according to criteria defined by the Ministry of Education (Article 1, paragraphs 1 and 2)(27).

One of these criteria is the best performance on the $\mathrm{Na}$ tional High school Assessment (Exame Nacional do Ensino Médio - ENEM).

\section{DISCUSSION}

Analysis of the available scientific literature on National Licensure Exam in the databases allows us to understand the characteristics, effects or impacts on the examinees. The NCLEX is an examination performed in the state where they have met the requirements for approval ${ }^{(13)}$. The National Council of Nursing administers the examinations whose average approval in the last 5 years was $82 \%{ }^{(21)}$. There are variations among Canadian jurisdictions, but approval is generally lower than in the USA, with an average national approval rating of $70 \%{ }^{(13-14,21)}$. Data from June 2016 shows an approval rate at around $43 \%{ }^{(25)}$ on Chinese proficiency tests.

Most texts compare approval ratings between gender, age group and origin. In these aspects, results indicate higher approval rates among men, with ages considered traditional or expected for graduation, of urban origin and whose parents had higher levels of education. On the other hand, students from minority groups, second-year students, adult students and students from diverse cultural backgrounds perform poorly on exams. Undergraduates of courses with more family responsibilities and with small children or pre-adolescents to care had worse performances in the NCLEX-RN. These results indicate a cycle of continuity of inequalities. There is a tendency for the examinee to be reproved more than once; the rate of approval among those who perform it for the first time is greater than among those who perform it two or more times ${ }^{(28-30)}$.

Few studies investigated the non-academic variables and the impact on passing the sufficiency test. Overall, research results indicate that in addition to the specific knowledge of Nursing there are other variables that determine approval, such as anxiety, self-esteem, age, and ethnicity. Thus, there are highly complex interrelationships between intellectual ability and non-academic variables that determine whether students will succeed or not at the exam. Factors related to emotional distress, fatigue and various tensions as well as family demands and responsibilities, financial difficulties and employment as conditions that contribute to students' failure to take the exam should be considered. Students who passed the exam had, during undergraduate course, a significantly higher performance in biology. Those who received the $C$ grade in the Nursing course until the end of the second year were the most likely to fail the exam ${ }^{(14,25-26,28-32)}$.

Being disregarded in the National Licensure Exam generates depression, isolation and exacerbates the financial difficulties, since the non-approval implies not being able to obtain employment even having to continue to pay the loans taken by the study. Rarely, nursing schools provide support for graduates who do not pass the exam. It is recognized that there is pressure from Nursing schools to maintain high pass rates in the USA Enrollment Exam, as well as a major concern with reputation, recruitment of qualified students, competition, and accreditation. However, the application of the exam has generated few results when the debate has as its central theme the protection of the public. It is said that National Licensure Exams are of high risk for students, teachers and nursing schools. Specially because they lead to the adoption of predictive tests and mechanisms to select students who are more likely to pass exams, with serious ethical consequences for the teaching-learning process ${ }^{(28,31-34)}$.

An editorial from Nursing Outlook ${ }^{(35)}$ argued that the National Licensure Exam tests basic knowledge, skills and attitudes that are believed to be safe for the beginning of a professionals' practice and not for training orientation. In the text, other more efficient mechanisms are presented, such as the certification examination to demonstrate expertise of a professional after entering a specific field of work. It is also questioned the ability of the exam to evaluate the performance of clinical skills and emerging areas in a society in constant transformation and knowledge being communicated in real time by social and scientific media.

In Brazil, the Bar Exam is offered three times a year for the undergraduate or law student, in the last year or in the last two semesters of the undergraduate course. In the case of Accounting, the study by Bugarim et al. ${ }^{(10)}$ analyzed the performance of participants in the issues of National Licensure Exam and found a decrease in approval levels, from $83.52 \%$ in its first edition in 2000 to $23.78 \%$ passing in 2012. In 20 exam editions, the average pass rate was $18 \%$.

Despite the low test approval rates, Accounting is among the five courses with the highest number of enrollments (total of 328,031 students, of both genders), according to the Higher Education Census. There seems to be more positive perception about the exam and its impact on the development and growth of the profession than actually reducing accounting courses in the country. By analyzing the answers of 220 accountants, we found that $81.82 \%$ believe that the exam provides professional appreciation and $82.73 \%$ realize that the exam helps select the most qualified professionals, although $53.61 \%$ believe that the exam system needs to be improved, in particular to suit the realities of the accountant ${ }^{(10-11,16)}$.

As for Accounting, despite the existence of the National Licensure Exam, there is no reduction in the numbers of courses, vacancies and enrollments in the Law undergraduate course in Brazil. The data from the Higher Education Census confirms this finding, in which Law is among the three courses with the highest number of vacancies, enrolled, subscribed and graduates, passing Accounting and Nursing in absolute numbers. There are around 1,150 Law courses in Brazil, with more than 220,000 places and about 95,000 graduates annually ${ }^{(10-11)}$.

However, in Law there are particularities to be considered. Graduates with a bachelor's degree in law can work in different contexts, including as a lawyer, if they pass the Bar Exam. Thus, to achieve the position of Undergraduate in Law is sufficient 
qualification by completion of the respective course and graduation ceremony. On the other hand, the lawyer is the one fit for the professional exercise attested against the National Licensure Exam $^{(12)}$. The Bar Exam does not restrict access to the labor market in positions other than that of Lawyer. This condition does not apply to Nursing, for which there is no other alternative for employment in the labor market other than as a Nursing, Technical or Nursing Assistant resulting from a training process.

In Nursing, there is the adoption of National Licensure Exam in industrialized countries or in those who are exporters of nurses to industrialized countries. It is important to note that, in most of these countries, the regulation of professional practice is controlled by government health agencies and not by professional advisory. In general, schools/courses are accredited, but there is no system of evaluation of trainees, as is the case of Brazil, with the National Undergraduate Performance Assessment (Exame Nacional de Desempenho de Estudantes - ENADE), by the Ministry of Education. That is, the mechanism adopted to evaluate the egress is the National Licensure Exam, since there are no other mechanisms of public regulation to assess the quality of teaching.

The findings presented in this study allow us to question the meanings of adoption of the National Licensure Exam in Brazil, in face of the characteristics and the profile of Nursing in our country. The origin of the nurses is of poor social strata, most of them are black and brown, $47.9 \%$ begin their careers at maturity, aged over 35 years; $43.1 \%$ migrated from the countryside of their states to the capital in search of vocational training and employment; $51 \%$ worked during their undergraduate nursing course. Many begin their career as a nursing assistant at 18 years old and as a nurse at $22^{(8)}$. Therefore, a National Licensure Exam would be promoting a "predatory professional selection", excluding Brazilian women who had the dream of higher education, particularly those who believed it was possible to ascend socially through the paths of Nursing.

Thus, we support our assumption that the National Licensure Exam for career access is a measure of accountability of individuals that accentuates social injustice and conditions of inequality and inequity that mark the Brazilian nursing. There is a great tendency of the examination to punish, individually, those students from different institutions who have managed to overcome social difficulties and who have had a pedagogical itinerary not always of quality, when the movement in favor of social justice would walk in the direction of thinking in the evaluation of examinations (or other devices) capable of assessing the sufficiency of courses/institutions.

There seems to be a paradox between the proposal of National Licensure Exam for Nurses, in a conjuncture of democratization of access to higher education of middle-level students from the popular strata of society. The affirmative actions instituted in 2005 positively influenced the increase of students' access to universities, among those benefiting from ProUni.

The privatization of higher education is a phenomenon present in 21 states and in the Federal District, because there are more students in the private sector than in the public ${ }^{(16)}$, not being an exclusive problem of nursing education. The Educational Development Plan (Plano de Desenvolvimento da Educação - $P D E$ ) fostered investments by the Ministry of Education, which led to the expansion of private education network. The ease of access to the vacancies came from governmental funding, through grants such as the University for All Program (ProUni) or the Loan Fund for Higher Education Students (FIES). There was also an expansion of the public-school system, through the Program to Support Federal University Restructuring and Expansion Plans ( Programa de Apoio a Planos de Reestruturação e Expansão das Universidades Federais - Reuni).

Nursing undergraduates belonging to the less favored economic classes benefited most from these affirmative actions, especially ProUni. In 2011, they offered more than 120,000 scholarships. Candidates from ProUni 2011 completed their undergraduate course in Nursing in 2016. According to data from the Ministry of Education, in 2013, nursing courses had the fourth largest number of female enrollments, corresponding to 194,166 women students ${ }^{(16)}$.

In an analytical perspective on the tendency of regulatory regimes, we see that the National Licensure Exam meets the logic of regulation over performance, because the focus is on the outcome of a given process (in the case of training) rather than on the process itself. This is a tendency of the more liberal societies whose accountability falls on the performance of individuals and what they are capable of demonstrating ${ }^{(11)}$.

Given this, the following are some of the indications that may contribute to overcome challenges of training nursing professionals in Brazil: a) recognizing that there are differences between the quality standards of nursing education in the world and, determine the desired standard for Brazilian Nursing; b) developing innovative teaching models; c) investing in the continuous preparation of the teacher, committed to teaching as a career; d) establishing "standards" of professional practice that can guide professional practice and education itself; e) urgent review of the National Curriculum Parameters to enhance training focused on social practice and the principles of the single health system; f) discussing models of certification and accreditation of Nursing Schools in Brazil; g) investing in professional residences, permanent education in service and proposals for certification of skills for professional practice after entry into practice; h) intensifying public regulation of education in Brazil stringently in the evaluation of courses, ensuring the specificities of Nursing.

\section{Study limitations}

We acknowledge the limitations of this study on the sources of information on National Licensure Exam over the world, as well as the access to systematized studies on the impacts and effects of its application, restricted to the USA and Canada.

Contributions to the area of nursing, health or public policy

Contributions to the area of nursing, health or public policy refer to the possibility of critically subsidizing the discussion about the quality of nursing education, the provision of distance education courses and, above all, influencing decisions about nursing. Bill 4930/2016.

\section{FINAL CONSIDERATIONS}

The National Licensure Exam is a device that is in the interregnum between training system and field of professional 
acting and marks this space as part of a regulation system to access practice.

The transposition of the field of training into the field of professional activity can take place in different ways. In a model of highly regulated and governed professions, such as health professions in Brazil, this transposition requires a regulatory body that operates as an accreditation system: a labor market reserves mechanism for members of the profession (qualified for such) and exclusion from the others. This accreditation adopts different instruments that pass through the registration in the regulatory agencies (which may or may not be preceded by exams/tests), besides submission or application of documents, payment of fees, etc.
The purpose of a professional licensing/accreditation is to protect the public from damages by setting minimum qualifications and skills for professionals at a basic level of security. Nursing is regulated because it is one of the health professions that presents greater risk of harm to the public if someone who is not prepared practices it.

Among the social characteristics of Brazilian Nursing are the inequalities and inequities of the profile of its members, the trajectory of training and insertion in the labor market. Our assumption is that the National Licensure Exam for career access is a measure of accountability of the individual that increases social injustice, in addition to penalizing those who seek to ascend socially through the paths of nursing.

\section{REFERENCES}

1. Brasil. Decreto $n^{\circ} 8.754$, de 10 de maio de 2016. Altera o Decreto n ${ }^{\circ} 5.773$, de 9 de maio de 2006. Dispõe sobre o exercício das funções de regulação, supervisão e avaliação de instituições de educação superior e cursos superiores de graduação e sequenciais no sistema federal de ensino [Internet]. Diário Oficial da República Federativa do Brasil. 2016[cited 2017 Nov 21]. Available from: http://www.planalto.gov.br/ccivil_03/_ato2015-2018/2016/decreto/D8754.htm

2. Brasil. Ministério da Saúde. Conselho Nacional de Saúde. Resolução nº 515, de 7 de outubro de 2016. Posicionamento contrário a autorização de todo e qualquer curso de graduação da área de saúde, ministrado na modalidade Educação à Distância (EaD) [Internet]. Brasília. 2016[cited 2017 Nov 21]. Available from: http://conselho.saude.gov.br/resolucoes/2016/Reso515.pdf

3. Brasil. Presidência da República. Subchefia para Assuntos Jurídicos. Lei $\mathrm{n}^{\circ}$ 13.415, de 16 de fevereiro de 2017. Altera as Leis $\mathrm{n}^{\text {os }}$ 9.394, de 20 de dezembro de 1996, que estabelece as diretrizes e bases da educação nacional, e 11.494, de 20 de junho 2007, que regulamenta o Fundo de Manutenção e Desenvolvimento da Educação Básica e de Valorização dos Profissionais da Educação [Internet]. Brasília, DF; 2017 [cited 2017 Nov 21]. Available from: http://www.planalto.gov.br/ccivil_03/_ato2015-2018/2017/lei/ L13415.htm.

4. Brasil. Presidência da República. Subchefia para Assuntos Jurídicos. Lei no 9.394, de 20 de dezembro de 1996. Estabelece as diretrizes e bases da educação nacional [Internet]. Brasília, DF; 1996[cited 2017 Nov 21]. Available from: http://www.planalto. gov.br/ccivil_03/leis/L9394.htm

5. Brasil. Presidência da República. Subchefia para Assuntos Jurídicos. Emenda Constitucional no 95 , de 15 de dezembro de 2016. Altera o Ato das Disposições Constitucionais Transitórias, para instituir o Novo Regime Fiscal, e dá outras providências [Internet]. Brasília, DF; 2016[cited 2017 Nov 21]. Available from: http://www.planalto.gov.br/ccivil_03/constituicao/emendas/emc/emc95.htm

6. Brasil. Câmara dos Deputados. Projeto de Lei 4930/2016. Altera a Lei nº 7.498, de 25 de junho de 1986. Regulamenta o exercício da enfermagem, para nela incluir a obrigatoriedade da realização de exame de suficiência para obtenção de registro profissional [Internet]. Brasília, DF; 2016[cited 2017 Nov 21]. Available from: http://www.camara.gov.br/proposicoesWeb/fichadetramitacao ?idProposicao $=2081598$

7. Brasil. Presidência da República. Subchefia para Assuntos Jurídicos. Lei n 7.498, de 25 de junho de 1986. Dispõe sobre a regulamentação do exercício da enfermagem, e dá outras providências [Internet]. Brasília, DF; 1986[cited 2017 Nov 21]. Available from: http://www.planalto.gov.br/ccivil_03/leis/L7498.htm

8. Brasil. Conselho Federal de Enfermagem-COFEn. Pesquisa Perfil da Enfermagem no Brasil. Banco de Dados. Bloco 1. Identificação socioeconômica/enfermeiros. 2013 [cited 2017 Nov 21]. Available from: http://www.cofen.gov.br/perfilenfermagem/\#dados-regionais2

9. Brasil. Ministério da Saúde. Conselho Nacional de Educação Câmara de Educação Superior. Resolução CNE/CES No 3 , de 7 de novembro de 2001. Institui Diretrizes Curriculares Nacionais do Curso de Graduação em Enfermagem [Internet]. Brasília. 2001 [cited 2017 Nov 21]. Available from: http://portal.mec.gov.br/cne/arquivos/pdf/CES03.pdf

10. Bugarim MCC, Rodrigues LL, Pinho JCC, Machado DQ. Análise histórica dos resultados do exame de suficiência do Conselho Federal de Contabilidade. Rev Contab Control[Internet]. 2014 [cited 2017 Nov 21];6(1):121-36. Available from: http://revistas. ufpr.br/rcc/article/view/33455/22671

11. Galvão N. Percepção dos contadores sobre o exame de suficiência do CFC. Revista Catarinense da Ciência Contábil [Internet]. 2016 [cited 2017 Nov 21];15( 45): 49-62. Available from: http://revista.crcsc.org.br/index.php/CRCSC/article/view/2200/1892

12. Fundação Getúlio Vargas. Exame de Ordem em números [Internet]. 2016 [cited 2017 Nov 21];3:52. Available from: https:// bibliotecadigital.fgv.br/dspace/bitstream/handle/10438/18493/oab_3_edicao_v4_web_espelhado.pdf

13. Humphreys, JA. Academic and Non-academic Predictors of Future Success on the NCLEX-RN Licensure Examination for Nurses. Doctoral dissertation, College of Saint Mary-Omaha [Internet]. 2008 [cited 2017 Nov 21] 106p. Available from: http://www.csm. 
edu/wfdata/files/Academics/Library/InstitutionalRepository/10.pdf

14. Arathuzik D, Aber C. Factors associated with National Council Licensure Examination-Registered Nurse success. J Prof Nurs[Internet]. 1998 [cited 2017 Nov 21];14(2):119-26. Available from: https://www.ncbi.nlm.nih.gov/pubmed/9549215

15. May PJ. Regulatory regimes and accountability. Regulation and governance [Internet]. 2007[cited 2017 Nov 21];1(1):8-26. Available from: http://onlinelibrary.wiley.com/doi/10.1111/j.1748-5991.2007.00002.x/pdf

16. Brasil. Ministério da Educação. Diretoria de Estatísticas Educacionais. Censo da educação superior 2013: resumo técnico. Brasília. 2015 [cited 2017 Nov 21]. Available from: http://download.inep.gov.br/download/superior/censo/2013/resumo_tecnico_censo_ educacao_superior_2013.pdf.

17. Brasil. Presidência da República. Subchefia para Assuntos Jurídicos. Lei n 12.249, de 11 de junho de 2010. Altera os Decretos-Leis $\mathrm{n}^{\text {os }}$ 9.295, de 27 de maio de 1946, 1.040, de 21 de outubro de 1969 [Internet]. Brasília, DF; 2010 [cited 2017 Nov 21]. Available from: http://www1.cfc.org.br/uparq/lei12249.pdf

18. Brasil. Conselho Federal de Contabilidade. Resolução n 1.301, de 17 de setembro de 2010. Regulamenta o Exame de Suficiência como requisito para obtenção ou restabelecimento de Registro Profissional em Conselho Regional de Contabilidade [Internet]. Brasília, DF; 2010[cited 2017 Nov 21]. Available from: https://crc-sc.jusbrasil.com.br/noticias/2399617/cfc-regulamenta-o-exame-de-suficiencia

19. Brasil. Presidência da República. Subchefia para Assuntos Jurídicos. Lei no 8.906, de 4 de julho de 1994 . Dispõe sobre o Estatuto da Advocacia e a Ordem dos Advogados do Brasil (OAB) [Internet]. Brasília, DF; 1994 [cited 2017 Nov 21]. Available from: http:// www.planalto.gov.br/ccivil_03/leis/L8906.htm

20. Fairclough N. Discourse and social change. Malden, USA: Polity Press; 2006. 251 p.

21. Atemafac J. Consequences for Nursing Graduates of Failing the National Council Licensure Examination (NCLEX). Doctoral Study Submitted in Partial Fulfillment of the Requirements for the Degree of Doctor of Education [Internet]. Walden University. 2014[cited 2017 Nov 21]. Available from: http://scholarworks.waldenu.edu/cgi/viewcontent.cgi?article=1173\&context=dissertations

22. Canadian Nurse Association. NCLEX-RN Exam resource[Internet]. 2015[cited 2017 Dec 12]. Available from: https://www.cna-aiic. ca/en/becoming-an-rn/rn-exam\#sthash.VFDir1vM.dpuf

23. College of Nurses of Ontario. Registered Nurse Examinations[Internet]. 2017[cited 2017 Dec 12]. Available from: http://www.cno. org/en/become-a-nurse/entry-to-practice-examinations/nclex-rn/

24. Australian Government Departament of Health. National Registration and Accreditation Scheme (NRAS) [Internet]. 2016[cited 2017 Dec 12]. Available from: http://www.health.gov.au/internet/main/publishing.nsf/Content/work-nras

25. Wang CC, Whitehead L, Bayes S. Nursing education in China: meeting the global demand for quality healthcare. Int J Nurs Sci[Internet]. 2016[cited 2017 Nov 21];3(1):131-6. Available from: http://www.sciencedirect.com/science/article/pii/S2352013215300296

26. Japanese Nursing Association. Nursing in Japan [Internet]. 2016 [cited 2017 Nov 21]. 20p. Available from: https://www.nurse.or.jp/ jna/english/pdf/nursing-in-japan2016.pdf

27. Brasil. Presidência da República. Subchefia para Assuntos Jurídicos. Lei no 11.096 de 13 de janeiro de 2005. Institui o Programa Universidade para Todos - PROUNI, regula a atuação de entidades beneficentes de assistência social no ensino superior; altera a Lei no 10.891, de 9 de julho de 2004, e dá outras providências [Internet]. Brasília, DF; 2005. [cited 2017 Nov 21]. Available from: http://www.planalto.gov.br/ccivil_03/_ato2004-2006/2005/lei/l11096.htm.

28. Amankwaa I, Agyemang-Dankwah A, Boateng D. Previous education, sociodemographic characteristics, and nursing cumulative grade point average as predictors of success in nursing licensure examinations. Nurs Res Pract[Internet]:682479. 2015[cited 2017 Nov 21]. 8p. Available from: https://www.hindawi.com/journals/nrp/2015/682479

29. Norton CK, Relf MV, Cox CW, Farley J, Lachat M, Tucker M, et al. Ensuring NCLEX-RN success for first-time test-takers. J Prof Nurs[Internet]. 2006[cited 2017 Nov 21];22(5):322-26. Available from: http://www.sciencedirect.com/science/article/pii/ S8755722305001699?via\%3Dihub

30. Grossbach A, Kuncel NR. The predictive validity of nursing admission measures for performance on the National Council Licensure Examination: a meta-analysis. J Prof Nurs[Internet]. 2011[cited 2017 Nov 21];27(2):124-8. Available from: http://www.sciencedirect. com/science/article/pii/S8755722310001201?via\%3Dihub

31. Poorman SG, Martin EJ. The role of nonacademic variables in passing the National Council Licensure Examination. J Prof Nurs [Internet]. 1991[cited 2017 Nov 21];7(1):25-32. Available from: http://www.sciencedirect.com/science/article/pii/875572239190071R?via\%3Dihub

32. Beeson SA, Kissling G. Predicting success for baccalaureate graduates on the NCLEX-RN. J Prof Nurs [Internet]. 2001 [cited 2017 Nov 21];17(3):121-7. Available from: http://www.sciencedirect.com/science/article/pii/S8755722301705157?via\%3Dihub

33. Roa M, Shipman D, Hooten J, Carter M. The costs of NCLEX-RN failure. Nurse Educ Today [Internet]. 2011 [cited 2017 Nov 21];31(4):373-7. Available from: http://www.sciencedirect.com/science/article/pii/S0260691710001425?via\%3Dihub

34. NLN Vision Series. The fair testing imperative in nursing education a living document from the national league for nursing. NLN Board of Governors February [Internet]. 2012[cited 2017 Nov 21]. 6p. Available from: http://www.nln.org/docs/default-source/ about/nln-vision-series-\%28position-statements\%29/nlnvision_4.pdf

35. Dorsey D. Letters to the Editor. Nurs Outlook [Internet]. 2006 [cited 2017 Nov 21];54:261-2. Available from: http://www. nursingoutlook.org/article/S0029-6554(06)00214-4/pdf 